\title{
4. Teleology, Cyclicality and Episodism: Three competing views of change in international relations
}

\author{
Michael Wesley
}

The discipline of international relations is divided by competing conceptions of change. International relations formed as a modern discipline in response to humanity's growing destructiveness as monarchs, states and societies repeatedly went to war with each other. Twentieth-century scholarship in international relations grew up alongside a hopeful project embodied in an international movement: that if subjected to rational research and the close attention of concerned citizens, inter-state relations could be prevented from descending into the carnage of another world war. ${ }^{1}$

The interwar years (1919-39) became the crucible in which this project was tested. Internationalism grew apace as a genuinely transnational movement, with the development of the Royal Institute of International Affairs (UK), the Council on Foreign Relations (US), the Australian Institute of International Affairs, the Institute of Pacific Affairs, and a range of like-minded institutions in many countries. Scholars such as James Bryce (1922), Goldsworthy Lowes Dickinson (1926), William Dunning (1923), Harold Laski (1935), Philip Marshall Brown (1923), Frederick Sherwood Dunn (1937), Thomas Lawrence (1919) and Sir Alfred Zimmern (1936) produced studies into the causes of war and international friction, and the prospects for these to be blunted by international law, international organisation, and the evolution of ethical forms of international thought. For a time, the combination of scholarship and activism appeared to be bearing fruit, with the formation of the League of Nations, the signing of the Kellogg-Briand Pact, and the drawdown of military arsenals in North America and Europe.

The problem was that Japan's Showa nationalists, Mussolini, Hitler and Stalin were not seized with such optimism. As Japanese, Italian, German and Soviet expansionism brought the world again to the brink of war, the occupant of the Woodrow Wilson Chair of International Relations at the University of Aberystwyth, EH Carr, published a trenchant critique of the idealist movement

\footnotetext{
1 Although modern international relations writing can be traced to the mid-nineteenth century (see Schmidt 1998) it is generally accepted that international relations coalesced as a self-conscious discipline after World War I, symbolised by the establishment of the first university chair in international relations at the University of Aberystwyth in 1919.
} 
in international relations under the title The twenty years' crisis (1939). Joined on the other side of the Atlantic in 1946 by Hans Morgenthau's publication of Scientific man versus power politics, a burgeoning movement of 'realist' critique condemned utopian liberal scholarship for being overly prescriptive in its analysis, flawed in its basic understandings of human nature, and naive in its policy prescriptions. A clear implication of the realist critique was that idealism ironically makes war more, not less, likely.

International relations consolidated as a discipline after World War II, deeply divided by what came to be called its first great debate. Arguably, however, the idealist-realist divide continues as the major schism in the discipline, reproduced anew with each generation of scholars and each expansion of the discipline into new countries, because each side of the schism embodies a concept of change in international relations that is fundamentally incompatible with that of the other side. The two alternative conceptions of change can be termed 'teleology' and 'cyclicality'. More recently, a third conception of change has emerged, borrowing heavily from institutional analysis in political science, which can be called 'episodism'.

\section{Teleology}

The teleological conception of international relations is convinced that international relations can evolve and has evolved over time into more sophisticated, rational and just forms of relations. Scholars in this tradition point to a variety of data to support this conviction. The past century has seen, for example, an unprecedented proliferation of international institutions charged with regularising international relations and taming the excesses of power politics (Krasner 1983, Ruggie 1993). The occurrence of major war between states is in steady decline (Mueller 2004), although the bestiality of conflicts within states continues to climb (Rummel 1994). Transnational trade, investment and prosperity continue to rise, making sustained conflict simply too costly for states to contemplate (Rosecrance 1986). The great and bloody ideological contests of the past have been resolved (Fukuyama 1989). The spread of democracy and growth of conceptions of justice have tamed the ravages of power politics (Doyle 1986, Beitz 1979). The combination of technology, travel and transnational culture has bred a situation in which hostility between peoples has become unthinkable (Deutsch 1949, Cooper 1998).

At the base of the teleological conception is a profound belief in the power of rational human agency to alter the irrational outcomes of international relations. Ultimately, international relations is about the interaction of human beings, and as a result of this the closed system of states inevitably evolves into a more 
predictable and stable society of states based on shared norms, objectives and expectations (Bull 1977). For some writers in this tradition, rationality and progress are injected into the affairs of states by harnessing the cold reason of human interests to overwhelm the irrational passions of relations among societies (Mitrany 1943, Haas 1964). Others argue that international relations are driven by intellectual constructs, and thus progress is provided by changing the content and expectations of those constructs (Ashley 1984, Walker 1993).

Teleological approaches to international relations can be divided into liberal and critical variants. For liberals, progress in international relations results from the slow triumph of human interests over human passions, of material concerns over emotive drives. To liberal writers in international relations, all that is required is for the same concerns that underpin stable and prosperous domestic societies to be unfettered and allowed to construct a stable and prosperous international society (Keohane and Milner 1996, Moravcsik 1997). If allowed free play, rationality will free states from self-defeating, zero-sum conceptions of their interests, enabling them to develop positive-sum outcomes. Ultimately, long-run liberal international orders will foster liberal rationality within states, as they realise the benefits that arise from stability and liberal norms justify their own contributions to the perpetuation of the liberal order (Keohane 1984).

Critical variants of the teleological school are united by their conviction that scholarship and practice in international relations are mutually reinforcing. Any writer's perspective on world affairs derives from his or her preferences for and interests in the way the world works - or does not (Cox 1981). Typically, critical writers take aim at conservative or liberal conceptions of international relations, arguing that such frameworks provide intellectual justification for particular power orders or economic orders, which in turn reward their intellectual defenders. To critical writers, it is the task of international relations to expose the workings of the power and economic orders and their intellectual superstructures, making the act of international relations scholarship an emancipatory project. In stripping away the intellectual garb of the workings of the current order, critical writers intend to expose the inequities and injustices of the current system, as a first step to changing that system. In this conception, human agency in the evolution of international relations is refined down to the international relations scholar him/herself as the radical agent of change.

To the teleological view of international relations, change is progressive and unidirectional. It may alternate between periods of slower and faster evolution, but in general the thought of international affairs reverting to the instability, hatreds and hierarchies of a century ago is as ludicrous as believing in a return to the era of monarchs, empires and European supremacy. International relations has moved on from the issues that preoccupied the internationalists of the interwar years, and is focused on new global challenges, many of which are 
the product of the unprecedented period of peace and prosperity following the end of World War II. Old problems of national hatreds, ideological rivalry and zero-sum conflict are now found only in the margins of world politics, and can be eradicated there through the injection of evolutionary statecraft as surely as medieval diseases can be wiped out through the introduction of modern medicine. The future may not be as colourful as the past, but it will be safer, more prosperous, more just, and more sustainable (Fukuyama 1992).

\section{Cyclicality}

The cyclical conception of international relations is deeply sceptical of the claims of the teleological conception. Writers in the cyclical vein argue that all of the optimistic portents of positive evolution paraded by the teleologists are largely surface dressing, while the deep rationality of relations between societies remains much the same as it was at the dawn of recorded history. We have seen periods of peace and prosperity before, they point out, which usually come to an end in a catastrophic conflict that resets the basic ordering of power in the world. The last period of globalist euphoria ended in the slaughter of World War I. Sovereignty is not being quietly superseded by transnational flows of money, goods, people and ideas; rather, the state is quietly extending its tentacles into ever broader areas of national life (Weiss 1998). Neither are states ceasing to invest in ever more destructive weapons systems (Ball 1993). International organisations are not curbing national rivalries; they are the new vehicles for rivalry (Grieco 1990, Mearsheimer 1994). Democracy, technology and education have not eradicated passions so much as turbocharged them (Kagan 2008). The end of ideological contestation has not resulted in a liberal utopia so much as a new era of religious or civilisational conflict (Huntington 1993, Juergensmeyer 1993).

At the base of the cyclical view of change is a profound belief that one can dip into practically any period of international history and find remarkable parallels with international relations today. The observations of Thucydides' fourth-century BC History of the Peloponnesian War are much quoted by cyclicalists, as are those of his seventeenth-century translator, Thomas Hobbes (Lebow 2005). The lessons of history, for the cyclical conception, are that only sober study of the recurring patterns of history, and the realistic conduct of human affairs according to these patterns, are the best routes to security and prosperity. On the other hand, misinformed idealism of the teleological variety is the shortest route to instability and violence. 
A view of human nature very different from the optimistic teleological view drives cyclical approaches to international affairs. However rational and virtuous humans are as individuals or within societies, as collectivities they become profoundly amoral (Niebuhr 1948). Whatever their morals or positive intentions, they are fated by the international structure of anarchy - whereby there is no power higher than the state, so each must look to protect its interests - to think and act in a profoundly self-interested way (Wight 1977). Because there is no higher authority to prevent predation, conflict and violence are ever present possibilities (Waltz 1959). As each state looks to bolster its own security, it thereby makes its neighbours less secure, prompting a never-ending 'security dilemma' that gives rise to high peacetime arms spending (Herz 1950). In such a state of nature, states and leaders may profess teleological principles, but these are most likely covers or vehicles for their power ambitions (Morgenthau 1948).

It is important to note that the cyclical view is not a theory of stasis; some evolution is acknowledged by writers within this tradition. They tend to see international history as the serial rise and decline of empires and great powers, which structure the world around them to suit their interests and to the preferences of their domestic orders and values (Knutsen 1999). Their rise is most often the result of material factors: economic dynamism, military technology, and/or demographic surges. The period of their ascendancy brings relative international peace, prosperity and progress (Kindleberger 1976). Often this period is marked by a rough balance between several great powers, the number of which determines the structure and stability of the international system at the time (Waltz 1979). But inevitably this period comes to an end, either due to the rise of competitors (Organski 1958) or because of the internal strains of maintaining hegemony (Kennedy 1988). The period of power transition, from one order to the next, is generally marked by great power war (Gilpin 1984).

Drawing inspiration from Machiavelli, cyclicalists believe the role of international relations is to provide clear policy advice on the current and future state of the cycle of history. It is their job to defuse any form of triumphalism, in which great powers can become convinced that history has ended with their ascendancy, and will stay that way (Layne 2003). By being clear-eyed about the inevitable cycle of history, they are able to provide policy advice that can minimise the violent aspects of power transition. In this sense, they are able to strike the occasional optimistic note, pointing to the US's peaceful usurpation of Britain's role as a world power in the mid-twentieth century, and the Soviet Union's peaceful implosion in the late twentieth century (Gaddis 1997). As such, theirs is not a rigidly mechanistic view of change. Surprising variation can occur despite the underlying logic remaining constant; as Mark Twain quipped, 'history seldom repeats itself, but it does tend to rhyme.' 


\section{Episodism}

A third variant - very much a minority strain - has emerged between the absolutes of teleologism and cyclicality. This is a tendency to view change as episodic and unpredictable in its timing, extent and direction. It is a conception of international relations as a realm of human activity that tends towards routines and stasis, accreting over time structures and forces of inertia that are periodically overwhelmed by underlying change. It is an approach that remains unconvinced by the unidirectional optimism of the teleologists or the determining pessimism of the cyclicalists. It is unconvinced by the data of both schools, preferring to remain open-minded and empirically oriented in thinking about change in international relations.

A major element in the inertia of contemporary international relations is seen to be the increasing routinisation of international life. The remarkable proliferation of international institutions has been a major part of this. International institutions, it is argued, preserve the power structures and expectations that existed at the time of their establishment. This makes them extremely hard to adapt to the evolution of international relations, and equally hard to abolish, given the reputation capital and hopes that have been invested in them over the years. The solution to the declining relevance of existing institutions is rather to simply establish new ones - which turn out to be equally inflexible and of declining relevance over time. The result of constant institutional creation is a progressive crowding of diplomatic schedules and a growing routinisation of international life - at the expense of issues on which real initiative and action is needed (Wesley 2011).

Inertia is the result of the difficulty and cost of change and the investment of the powerful in current ways of doing things. Several factors play interlocking roles in supporting inertia and routinisation. Institutions and relationships often embody high start-up and sunk costs. Often they were negotiated at an opportune time that is unlikely to recur; inevitably they are seen, for all of their defects, as being better than no institution, agreement or relationship at all. Existing institutions exert strong learning effects, by favouring those who adapt their strategies and expectations to the existing rules. These are buttressed by adaptive expectations that favour existing ways of doing things over innovation. Bureaucratic objectives tend to be moulded by institutional possibilities, rather than vice versa. Routinisation incentives tend to multiply activities that comply with existing structures and crowd out opportunities for innovation. Competency traps breed familiarity with existing rules and bureaucratic training becomes oriented to most effectively using those rules (March and Olsen 1998). 
The very anarchic nature of international relations means that established routines and institutions are heavily invested in, simply because they enable inter-state and intercultural interaction. Often such institutions are modes of communication (the dominant lingua franca) or transaction (the dominant international currency) that exhibit remarkable 'sticky power' simply because of their usefulness and the lack of viable alternatives (Mead 2004, Eichengreen 2009). Often their usefulness hides considerable weaknesses.

Ultimately, however, change will occur because humanity is subject to constant change: material, technical, developmental, moral. Eventually the sum of all of this underlying change will expose the inadequacies of existing routines, institutions and relationships. Europe's empires will collapse in the space of a decade. A Berlin Wall will be torn down overnight. Two planes will crash into the World Trade Centre. Depending on the gap that is drawn between existing routines and the new reality, a period of intense experimentation will followand the resulting routines, institutions and relationships will soon accrete all of the attributes of inertia.

Episodic change cannot be categorically classified as either teleological or cyclical. One instance - the fall of the Berlin Wall - may look like evidence of teleological progress, while another - the attack on the World Trade Centremay be redolent with the rhymes of history.

\section{Conclusion}

Change remains a central problem in the discipline of international relations. As an intellectual exercise and a policy science, international relations is inescapably future-focused. Conditioned to the constant expectation of unforeseen developments, its reaction has been to study change in history as a way of projecting some predictability into the future. But the divides between its three perspectives on change - teleologism, cyclicality and episodismare ultimately unresolvable. There is, quite simply, enough data to support each of these three positions. No event has yet enabled any of the variants to permanently discredit one of the others. And so international relations will continue to be a discipline united by its deeply divided conceptions of change. 


\section{References}

Ashley, RK (1984) The poverty of neorealism. International Organization 38(2): 225-86.

Ball, D (1993) Arms and affluence: military acquisitions in the Asia Pacific region. International Security 18(3) Winter: 78-112.

Beitz, CR (1979) Political theory and international relations. Princeton University Press, Princeton.

Brown, PM (1923) International society: its nature and interests. Macmillan Company, New York.

Bryce, J (1922) International relations. Macmillan, London.

Bull, H (1977) The anarchical society: a study of order in world politics. Macmillan, London.

Carr, EH (1939, 2nd ed 1964) The twenty years' crisis, 1919-1939. Harper and Row Publishers, New York.

Cooper, R (1998) The breaking of nations. Atlantic Books, London.

Cox, RW (1981) Social forces, state and world orders: beyond international relations theory. Millennium 10(2) Summer: 126-55.

Deutsch, K (1949) Political community in the North Atlantic area. Princeton University Press, Princeton.

Dickinson, GL (1926) International anarchy 1904-1914. The Century Co, New York.

Doyle, M (1986) Liberalism and world politics. American Political Science Review 80(4) December: 1151-69.

Dunn, FS (1937) Peaceful change: a study of international procedures. Council on Foreign Relations, New York.

Dunning, W (1923) Liberty and equality in international relations. American Political Science Review 17 (February): 1-16.

Eichengreen, B(2009) Exorbitant privilege: the rise of the dollar. Oxford University Press, Oxford.

Fukuyama, F (1989) The end of history? The National Interest 16 (Summer): $3-18$. 
Fukuyama, F (1992) The end of history and the last man. Penguin Books, London.

Gaddis, JL (1997) We now know: rethinking Cold War history. Oxford University Press, Oxford.

Gilpin, R (1984) War and change in world politics. Cambridge University Press, Cambridge.

Grieco, J (1990) Cooperation among nations. Cornell University Press, Ithaca.

Haas, EB (1964) Beyond the nation-state: functionalism and international organisation. Stanford University Press, Stanford.

Herz, J (1950) Idealist internationalism and the security dilemma. World Politics 2: 157-80.

Huntington, SP (1993) The clash of civilizations? Foreign Affairs (Summer): 22-49.

Juergensmeyer, M (1993) The new Cold War? Religious nationalism confronts the secular state. University of California Press, Berkeley.

Kagan, RD (2008) The return of history and the end of dreams. Atlantic Books, London.

Kennedy, P (1988) The rise and fall of the great powers. Random House, New York.

Keohane, RO (1984) After hegemony. Princeton University Press, Princeton.

Keohane, RO and Milner, HV (1996) Internationalization and domestic politics. Cambridge University Press, Cambridge.

Kindleberger, C (1976) The world in Depression, 1929-1939. University of California Press, Berkeley.

Knutsen, T (1999) The rise and fall of world orders. Manchester University Press, Manchester.

Krasner, SD (1983) International regimes. Cornell University Press, Ithaca.

Laski, H (1935) World politics and personal insecurity. McGraw-Hill, New York.

Lawrence, $\mathrm{T}$ (1919) The society of nations: its past, present and possible future. Oxford University Press, New York.

Layne, C (2003) The peace of illusions. Cornell University Press, Ithaca.

Lebow, RN (2005) The tragic vision of politics. Cambridge University Press, Cambridge. 
Change!

March, JG and Olson, JP (1998) The institutional dynamics of international political orders. International Organization 52(4): 943-69.

Mead, WR (2004) Power, terror, peace and war. Knopf, New York.

Mearsheimer, JJ (1994) The false promise of international institutions. International Security 19: 5-49.

Mitrany, D (1943) A working peace system. Royal Institute of International Affairs, London.

Moravcsik, A(1997)Taking preferences seriously: a liberal theory of international politics. International Organization 51: 513-53.

Morgenthau, HJ (1946) Scientific man versus power politics. University of Chicago Press.

Morgenthau, HJ (1948) Politics among nations. Knopf, New York.

Mueller, J (2004) The remnants of war. Cornell University Press, Ithaca.

Niebuhr, R (1948) Moral man and immoral society: a study in ethics and politics. Scribner's Sons, New York.

Organski, AFK (1958) World politics. Knopf, New York.

Rosecrance, $\mathrm{R}$ (1986) The rise of the trading state. Basic Books, New York.

Ruggie, JG (1993) Multilateralism matters: the theory and praxis of an organizational form. Columbia University Press, New York.

Rummel, RJ (1994) Power, genocide and mass murder. Journal of Peace Research 31(1): 1-10.

Schmidt, BC (1998) The political discourse of anarchy: a disciplinary history of international relations. State University of New York Press, Albany.

Walker, RBJ (1993) Inside/outside: international relations as political theory. Cambridge University Press, Cambridge.

Waltz, KN (1959) Man, the state and war. Columbia University Press, New York.

Waltz, KN (1979) Theory of international politics. Addison-Wesley, Boston.

Weiss, L (1998) The myth of the powerless state. Polity Press, Cambridge.

Wesley, M (2011) There goes the neighbourhood: Australia and the rise of Asia. Newsouth Books, Sydney. 
Wight, M (1977) Power politics. Penguin, London.

Zimmern, A (1936) The League of Nations and the rule of law. Macmillan and Co., London. 
This text is taken from Change! Combining Analytic Approaches with Street Wisdom, edited by Gabriele Bammer, published 2015 by ANU Press, The Australian National University, Canberra, Australia. 